Discussion Paper No. 04-62

Computer Use and the Employment Status of Older Workers An Analysis Based on Individual Data

Katrin Schleife

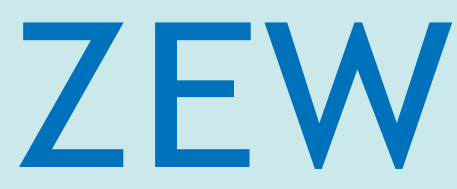

Zentrum für Europäische Wirtschaftsforschung $\mathrm{GmbH}$

Centre for European

Economic Research 


\title{
Discussion Paper No. 04-62 \\ Computer Use and the Employment Status of Older Workers - An Analysis Based on Individual Data
}

\author{
Katrin Schleife
}

Download this ZEW Discussion Paper from our ftp server:

\author{
ftp://ftp.zew.de/pub/zew-docs/dp/dp0462.pdf
}

Das Papier entstand im Rahmen des Forschungsprojekts „IKT-Einsatz und die Altersstruktur der Beschäftigten“ im Auftrag der Landesstiftung Baden-Württemberg.

The paper was written as part of the research project "ICT usage and the age structure of employees" commissioned by the Landesstiftung Baden-Württemberg foundation.

Die Discussion Papers dienen einer möglichst schnellen Verbreitung von neueren Forschungsarbeiten des ZEW. Die Beiträge liegen in alleiniger Verantwortung der Autoren und stellen nicht notwendigerweise die Meinung des ZEW dar.

Discussion Papers are intended to make results of ZEW research promptly available to other economists in order to encourage discussion and suggestions for revisions. The authors are solely responsible for the contents which do not necessarily represent the opinion of the ZEW. 


\section{Non-Technical Summary}

In Germany, the labor market participation of older workers decreased sharply during the last three decades. A growing discrepancy between actual and statutory age of retirement indicates, that employers and employees extensively use the possibilities of early retirement provided by the German public retirement system. As this period is characterized by a rapid diffusion of information and communication technologies (ICT) across German firms, these changes are often cited as a possible reason for the trend of early withdrawal from employment, as older workers may fall behind in adapting to new computer-related skill requirements. It is often argued that the skills of older workers are outdated, making them more exposed to technology shocks than younger workers. Or that older workers have lower learning capabilities. In addition, the incentive to invest in training may be lower for both older workers themselves and their employers as they will have less time to capture the returns to the training investment. As a result productivity and wages of older workers who do not use a computer may be lowered when new technologies are implemented and incentives to retire earlier may be increased for older employees. In Germany, the wage structure provides incentives for employers to send older workers into retirement, as wages for older workers are relatively high and inflexible.

This study tests the hypothesis that older workers who do not use a computer on the job have a higher probability of changing their employment status. In the analysis, an employment status change means that workers who are employed full-time in 1997 become employed part-time, retired or unemployed in 2001. In a first step the determinants of computer use of older workers in 1997 are studied. It turns out that the probability of using a computer declines with age, and increases with wage and occupational position. In a second step, the correlation between older workers' computer use and employment status change is analyzed. The results show that the negative bivariate correlation between these two variables vanishes when considering additional individual and firm-related characteristics. This indicates that other factors than computer use determine the voluntary or involuntary decision of older workers to change their employment status. The study is based on the German Socio-Economic Panel data. 


\title{
Computer Use and the Employment Status of Older Workers - An Analysis Based on Individual Data*
}

\author{
Katrin Schleife ${ }^{\dagger}$
}

September 2004

\begin{abstract}
This paper analyzes computer use by older male employees and estimates the impact of computer use on their employment status, based on individual data from the German Socio-Economic Panel (GSOEP) for the years 1997 and 2001. In line with previous research on the diffusion of new technologies, a strong and negative relationship between the age of workers and computer use is found. In addition, the impact of occupational status and hourly wage on computer use is significantly positive. However, the estimated impact of computer use on the change in employment status of older workers becomes insignificant when controlling for individual and firm-specific characteristics.
\end{abstract}

JEL-Classification: J14, J26, O33

Keywords: computer use, older workers, employment status

*Acknowledgments: The paper was written as part of the research project "ICT usage and the age structure of employees" commissioned by the Landesstiftung Baden-Württemberg foundation. Helpful comments by Horst Entorf, Julia Häring, Thomas Hempell, Peter Jacobebbinghaus, Alexandra Spitz and Thomas Zwick are gratefully acknowledged.

${ }^{\dagger}$ Address: ZEW Mannheim, Centre for European Economic Research, Research Group Information and Communication Technologies, P.O.Box 103443, D-68034 Mannheim, Germany, email: schleife@zew.de 


\section{Contents}

1 Introduction 1

2 Background discussion $\quad 4$

2.1 Previous research results . . . . . . . . . . . . . 5

2.1.1 Productivity of older workers . . . . . . . . . . 5

2.1.2 Computer technology and skill requirements of jobs . . . . 6

2.1.3 Computer use and wages . . . . . . . . . . . . 7

2.1.4 Computer use and the retirement decision of workers . . 8

2.2 Retirement regulations in Germany . . . . . . . . . . . . . . . 10

3 The data $\quad 12$

4 Results 13

4.1 Descriptive statistics . . . . . . . . . . . . . . . . . 13

4.2 Estimating the determinants of computer use . . . . . . . 18

4.3 Estimating the impact of computer use on the employment status change ......................... 24

5 Concluding remarks $\quad 30$

$\begin{array}{ll}\text { References } & 41\end{array}$ 


\section{Introduction}

In recent years, increasing life expectancy and decreasing natality have caused an aging of populations in industrialized countries worldwide. This trend can be seen in Germany, too, and it should also be observable on the German labor market. This is not the case, however. To a large extent older workers use the possibilities of early retirement and hence the average age of the German work force is stagnating. ${ }^{1}$ In West Germany, between 1970 and 2000 the labor force participation rate of men aged 60 to 64 has sharply declined by 37 percentage points (from $70 \%$ to $33 \%$ ) and the rate of men aged 55 to 59 has decreased by 10 percentage points to $78 \%$ (Herfurth and Kohli, 2003). This reflects the propensity among older workers to retire early. On the other hand, the participation rates of male workers between 30 and 45 years remained relatively stable over time and amounted to more than $90 \%$ up to the year 2000 (Federal Statistical Office Germany, $\left.1991^{2}\right)$.

One explanation for this trend are several reforms of the German pension system in this period, which have opened up various possibilities to retire early (see Section 2.2). In addition, the rapid diffusion of information and communication technologies (ICT) across German firms is often cited as a possible reason for this development in the labor market. The use of computers on the job has become common practice. At the end of 2002 about half of German employees predominantly worked with a computer at the workplace (this is the result of a ZEW-survey in 2002). This may cause older workers to fall behind in adapting to new computer-related skill requirements. As discussed in Borghans and ter Weel (2002) it is often argued that the skills of older workers are outdated, making them more exposed to technology shocks than younger workers. Another argument is that older workers have lower learning capabilities. Since the introduction of new technologies might require additional training, older workers may avoid using new equipment. In addition, the incentive to invest in training may be lower for both older workers themselves and their employers as they will have less time to capture the returns to the training investment. As a result, productivity and wages of older workers who do not use a computer may be lowered when new

\footnotetext{
${ }^{1}$ In West Germany, the average age of the labor force remained at about 38 to 39 years between 1970 and 1990 (in Germany in 2002: 40 years).

${ }^{2}$ The data were taken from German Statistical Yearbooks.
} 
technologies are implemented and incentives to retire earlier may be increased for older employees. ${ }^{3}$ In Germany, the wage structure provides incentives for employers to send older workers into retirement, as wages for older workers are high and cannot be easily adjusted (Herfurth and Kohli, 2003). Borghans and ter Weel (2002) state that the use of computers is likely to be determined mainly by the wage level and not by age. There is a positive relationship between wages and computer use as the benefits of time saved by computer use are higher when the worker earns a higher hourly wage. However, the regression results by Borghans and ter Weel (2002) show no significant wage premium on computer skills.

A related question concerns the fact that the decision to take part in IT training and the decision about the age of retirement are possibly mutually dependent. Friedberg (2003) finds that computer users have been retiring later than nonusers in the 1990s. She presents two reasons for this finding. On the one hand, people who decide to invest in computer training want to retire later in order to use the acquired skills for a longer time. On the other hand, there are people who decide to retire later and who find it worthwhile to invest in computer training as for them enough time is left in order to amortize the investment. Thus, Friedberg (2003) presumes that age alone does not explain why older workers use computers less than younger workers but rather that impending retirement affects the decision of investing in training. In addition, concerning the retirement decision Bartel and Sicherman (1993) state that it makes a difference whether technological changes occur as a permanent process or as a shock. Older workers suffer particularly from the latter because their human capital abruptly depreciates and their experience cannot be used in the adoption process.

Thus, as human capital theory predicts there are disincentives for older workers as well as their employers to invest in older workers' training because of higher opportunity costs of investing in training due to their higher wages, on the one hand, and a shorter time horizon that is left to reap the benefits of the training

\footnotetext{
${ }^{3}$ As Lazear (1979) points out, both firm and worker have an incentive to find a wage contract such that the worker is paid less than his marginal product when he is young and more than his marginal product when he is old to compensate. Thus, although productivity declines with age, wages will not be adjusted downward by the firm when the worker is old in order to avoid shirking and in order to avoid a loss of reputation when this behavior is observed by younger workers. This is true only for long-term contracts, however. If contracts are short-term older workers will not get this wage advantage.
} 
investment, on the other hand. Besides these rational and nondiscriminatory factors, fewer training opportunities of older workers can also be the result of discriminatory processes. Koller and Gruber (2001) find different kinds of prejudices with respect to the specific characteristics of younger and of older workers concerning their abilities and their attitudes to work. On the one hand, older workers are less flexible and less adaptable to technological and organizational changes, having less eagerness to learn and a lower ability to work under pressure. On the other hand, they are more experienced, conscientious, reliable and loyal compared to younger workers. Another good description of these potential differences in characteristics between younger and older workers in connection with the preferences of employers to hire workers from one age group or the other is made for the federal state of Baden-Württemberg in Strotmann and Hess (2003). In addition, Koller and Gruber (2001) find that in many firms older workers do other kinds of jobs than younger ones. Therefore, Boockmann and Zwick (2004) point out that it is not only the differences in the characteristics of younger and older workers that matters, but how important different characteristics are for the particular job. By statistically weighting the characteristics they find that on average older workers are not evaluated as being inferior to younger workers.

Using the share of computer users as a measure of new technology diffusion, this paper contributes to the research on the relationship between new technology use and the labor market participation of older workers by analyzing two main hypotheses:

- Older workers are less likely to use a computer at work than younger workers.

- If older workers use a computer at work they are more likely to stay in full-time employment. This means that older workers who do not use a computer have a higher probability of working only part-time, of retiring early or of becoming unemployed.

The empirical analyses are based on individual data from the German SocioEconomic Panel (GSOEP) and show that: 
1. The probability of using a computer on the job declines with increasing age.

2. The impact of occupational status as well as of hourly wage on the probability of using a computer is significantly positive.

3. There is a bivariate correlation between computer use and the probability of continuing to work full-time in the analyzed sample of older workers. Controlling for various other factors, the impact of computer use on employment status becomes insignificant, however. Therefore, among the analyzed age group computer use does not seem to affect the probability of changing the employment status.

4. Much more important for the probability of changing the employment status is the occupational status of older workers.

5. As expected, age has a significantly positive effect on the probability of changing the employment status as more and more workers retire when they get older. There is no indication of a higher probability in the age group corresponding to statutory early retirement age (e.g. 60 or 63).

6. The educational level and the tenure of the workers show no significant effects on the probability of changing the employment status.

The remaining part of this paper is organized as follows: Section 2 gives a short overview on the results of previous studies. The empirical framework and the data are described in Section 3. Section 4 presents the results, and Section 5 concludes.

\section{Background discussion}

This section consists of two parts. The first one gives an overview of various studies that touch on the connection between computer use and the employment status of older workers. The second part describes the regulations concerning early retirement and part-time work in Germany. 


\subsection{Previous research results}

In the economic literature alternative hypotheses are discussed in order to explain why the labor force participation rate of older workers declines and why some workers retire earlier than others. In this subsection, first, studies are presented that concentrate on older workers' productivity as one of the factors that influence their employment situation. Then, after taking a look at studies that discuss the impact of computer technology on skill requirements in general as well as on wages, research results are summarized that concentrate on the relationship between computer use and employment status of older workers.

\subsubsection{Productivity of older workers}

The labor productivity of workers varies with their age. Skirbekk (2003) presents various studies analyzing the pattern and the causal factors of these productivity differentials. Several individual and firm related characteristics determine the productivity of workers. As the weight of these causal factors is steadily changing due to biological or labor market reasons also productivity does not remain unchanged during working life. Several studies presented by Skirbekk (2003) find a decline of mental abilities with age after maximum values are reached in the 20 s and early 30s. The decline becomes even sharper for older workers above the age of about 50. Part of this 'technical skill obsolescence' (Rosen, 1975) may be compensated by longer experience and higher levels of job knowledge of older workers. However, as there are changes in the market value of skills due to technological progress, cognitive abilities (such as learning, or adjusting to new ways of working) become crucial, while a long work experience may become less essential ("economic skill obsolescence" (Rosen, 1975)). Thus, the relative labor productivity of older workers declines. As they are paid above their marginal productivity (Lazear, 1979) employers may try to send them into early retirement ("retirement push").

Moreover, Skirbekk (2003) presents various approaches to measure the productivity of individuals at different ages. One of these measures, the labor market participation rate of workers of different age groups, is also explained by Herfurth and Kohli (2003). They state that the development of individual labor produc- 
tivity with age is not easy to evaluate. The observation of frequent job dismissals of older workers and the appraisal that employers prefer to displace those workers with low productivity is often supposed to be an indirect measure of the decreasing labor productivity with age. However, Herfurth and Kohli (2003) suppose that this last explanation is distorted because of specific institutional regulations in Germany that facilitate the dismissal of older workers by sending them into early retirement ('retirement pull'). Therefore both aspects, retirement push and retirement pull factors, are considered below when analyzing employment status changes of older workers.

\subsubsection{Computer technology and skill requirements of jobs}

Using different definitions and measures of technology, empirical studies mostly support the notion of a skill-biased technological change. Chennells and Van Reenen (2002) survey economic research on the effects of technological change, such as the diffusion of computers, on skills, wages and employment. They find evidence of a positive correlation between technology and the demand for skills.

Recent papers concentrate on the reasons of the shifts in the type of skills demanded in the labor market. One of the reasons may be changes in the skill composition within jobs. Autor et al. (2002, 2003) analyze the impact of technological changes on the design and the skill requirements of jobs using data for the U.S. They find that computers are introduced in particular "to automate tasks that can be described in terms of rules-based logic" (Autor, Levy, and Murnane, 2002, p. 445). At the same time, this technological change leads to a re-organization of those tasks that are not computerized. The authors support the widespread theory that computers and education act as complements, and that computerization therefore leads to an increase in the relative demand for highly skilled labor, especially as the price of computer capital is further declining owing to IT innovations. Spitz (2003) describes the changes in the occupational structure of employment due to the diffusion of IT and analyzes the changes in skill requirements among occupations, using data of German employees. Her findings support the hypothesis that IT capital substitutes for repetitive tasks and that it complements for analytical, interactive and computational skills. Therefore, a shift in the task composition of occupation due to IT capital leads to an increase 
in the demand for more highly educated labor.

The relationship between changes in skill requirements of jobs due to innovation and the age structure of the workforce is not clear. Aubert, Caroli, and Roger (2004) point out that, on the one hand, as older workers are more experienced and have a higher level of knowledge they should benefit from the increasing demand for highly skilled labor. On the other hand, the impact of technological progress on older workers may be negative if it leads to a depreciation of a given stock of human capital ('economic skill obsolescence') ${ }^{4}$. However, Bartel and Sicherman (1993) conclude that older workers most notably suffer from technological shocks as they lead to an abrupt depreciation of knowledge. Permanently high rates of technological progress can be better accompanied by continued training activities and may therefore be a minor problem.

\subsubsection{Computer use and wages}

Developing a model to explain how computer technology has changed the labor market, Borghans and ter Weel (2004) conclude that it is not the task composition of a particular job that changes after the introduction of computers at the workplace. Rather the relative time needed to perform the tasks changes as the time requirements for tasks taken over by a computer are reduced. Relative costs of doing a certain task are higher for highly paid workers. Therefore, firms seem to upgrade their workforce, as they gain more when they give those highly-skilled workers a computer in order to reduce the time they need to perform a task. This result is consistent with the finding presented in other research papers that workers who eventually use a computer are already better paid before the introduction of this new technology. In the estimations of computer use below, wage is one of the explanatory variables to test its impact. In line with the finding given above the correlation turns out to be significantly positive. But there is no clear evidence given in the data that the causality goes in this direction.

DiNardo and Pischke (1997) point in a similar direction. Comparing data for Germany and the U.S. they find a significantly positive correlation between computer

\footnotetext{
${ }^{4}$ For a comprehensive description of the causes, models and estimations of skill obsolescence see De Grip and Van Loo (2002).
} 
use and wages but express some skepticism regarding the notion that computer use directly raises a worker's productivity. Rather, the return to computer use can be attributed to unobserved heterogeneity. Also Entorf and Kramarz (1997) come to this result by analyzing the impact of computer-based new technologies on productivity and wages based on the French Labor Force survey. Computer users were more productive and already earned higher wages before they got a computer. In addition, they find that after the introduction, those highly paid workers benefit not from mere use of a computer, but their higher unobserved ability leads to higher wages due to the workers' productivity gain when acquiring experience in using them.

Focusing on the comparison between older and younger workers, Borghans and ter Weel (2002) analyze the determinants of computer use as well as the relationship between computer skills and wages within different age groups. They use British data and conclude that computer use does not depend on age. Instead, it is mainly determined by the wage level. Highly paid workers are more likely to use a computer than low-paid workers. Two important reasons for this result are that the benefits from the amount of time saved by using a computer as well as the benefits of additional training are higher for employees who earn higher wages (and have a higher qualification). Although the regression results show that younger workers embody more computer skills than older workers, Borghans and ter Weel (2002) state that this finding does not matter for the workers, because they find no labor-market returns to computer skills in terms of wage premiums: Workers who use the computer for a longer period of time receive the same wages, regardless of their level of computer skills. Thus, they conclude, older workers should not have more trouble in adapting to a computerized work environment.

\subsubsection{Computer use and the retirement decision of workers}

Besides the impact on wages, computer use may have an impact on the retirement decision of employees (and employers). The relationship between computer use of workers and their retirement decision is described by Friedberg (2003). Using U.S. data she concludes that not only the age of workers but also impending retirement affects the decision of using a computer on the job and, in addition, that computer users retire later than non-users. Moreover, Friedberg (2003) finds 
that the relationship between computer use and retirement is mutual. Workers who choose to invest in computer training retire later, and workers who decide to retire later are more likely to invest in further training and acquire computer skills. By analyzing cohorts, Friedberg (2003) shows that the rate of computer use was essentially flat over most ages up to an age of 53. Only for people in their late fifties and sixties the shares of computer users fell behind as they approached retirement although they had previously kept pace with the younger workers. The analysis implies that computer use causes later retirement: It "raised the likelihood of continuing to work by up to 25-30\%. These effects are strongest for workers in their late fifties" (Friedberg, 2003, p. 527).

The reduction in the labor force participation of older workers due to technological progress is also analyzed by Ahituv and Zeira (2000). Using data for the U.S., they conclude that the labor supply of older workers is negatively correlated with the average rate of technological progress across sectors due to an "erosion effect". Older workers tend to reduce training efforts because their career horizon is short, and hence technological changes lead to an erosion of their human capital. Young workers get an advantage in knowledge and become more productive. In the end this leads to a fall in relative income of older workers and they tend to reduce their labor supply by using the possibility to retire early.

The paper of Bartel and Sicherman (1993) is another study discussing the retirement decision of workers with regard to technological changes. They use data of older men in the U.S. labor force between 1966 and 1983. The authors distinguish between high rates of technological change in particular industries and technological shocks. They conclude that workers in industries with high rates of technological change retire later because they have to perform permanent onthe-job training, keeping their skills up-to-date. The technological changes lead to high depreciation rates of human capital and reduce the returns to training investments. Thus, if there is a net positive correlation between on-the-job training and technological change (i.e., the positive effect of technological change on the profitability of training is stronger than the negative effect occurring through the depreciation rate), the retirement age of workers is rising. However, an unexpected increase in the rate of technological change leads to an abrupt depreciation of human capital and thus to a drop in the retirement age of workers. Bartel and Sicherman (1993) summarize that technological changes do not always abridge 
the careers of older workers. Permanently high rates of technological change cause a postponement of retirement, whereas technological shocks lead to earlier retirement.

This paper contributes to the research on the retirement decision of older workers in correlation with their computer use. The main hypothesis is that computer use has a positive impact on the older workers' probability of continuing to work full-time.

\subsection{Retirement regulations in Germany}

In Germany ${ }^{5}$, workers face several possibilities to leave work before the regular retirement age, either because they want to leave or because their employers induce them to go. Some of the most important regulations are described in this section.

Since the middle of the 1970s the retirement age in Germany has become more flexible. This is mainly due to reforms of the German pension system, most notably the reform of 1973. Since then, older workers face different legitimate possibilities to work part-time and to retire before the regular retirement age (65 for men and women). Workers with an insurance history of more than 35 years are allowed to retire with an age of 63 . Old age pensions are paid from age 60 on if certain conditions (being severely disabled or unable to work) are met. In addition, before the age of 60 other kinds of public transfers can be used, such as unemployment compensation in combination with severance pay, to abort employment. In the following years these regulations led to a reduction in the average age of retirement of men (women) from 62.2 (61.6) years in 1973 to 58.4 (59.5) years in 1981. It further declines thereafter. In 2000 it was 59.8 for men and 60.5 for women (Herfurth and Kohli, 2003).

In East Germany, a new and temporary retirement regulation was applied. Between 1990 and 1992 (after the German reunification), men and women, who were registered unemployed and were qualified to receive unemployment benefits, were

\footnotetext{
${ }^{5}$ For an overview about the regulations and their effect on the labor force participation of older workers in different European and non-European countries see Schleife (2004).
} 
allowed to leave the labor force from age 55 on. They received a payment of $65 \%$ of their net income of the last three months for a maximum period of five years. The impact of this regulation on the East German labor market was strong and influential for many years. In 1990 only 10\% of the East German men and 30\% of the East German women aged 55 to 59 were unemployed. Two years later these shares had risen to nearly $60 \%$ for men and nearly $80 \%$ for women (Ernst, 1996).

In 1992 and 1999 reforms were launched in order to simplify the old age pension system. These reforms aim to stop the early retirement trend by abolishing exceptions for unemployed, for part-time employees and for women and thus by increasing their "normal" retirement age to 65 (Berkel and Börsch-Supan, 2003). Partial retirement of workers older than 54 years is possible, but it is subsidized only if the employer additionally engages a person that was unemployed before. ${ }^{6}$ Up to the year 2012 early retirement is still possible but only at the expense of retirement pension reductions of $3.6 \%$ for every year before the age of 65 (Koller, 2001). However, this adjustment factor is not large enough to reduce all financial incentives to retire early.

For the older workers of the year 1997 who are analyzed in this paper mainly the 1972 legislation was relevant as the reform of 1992 had not been fully phased in. ${ }^{7}$ However, their retirement behavior up to the year 2001 was to some extent already influenced by the reduction of the possibilities to retire early. If the men of the analyzed sample use the possibility of early retirement to a large extent, this should be visible in the estimation results in section 4.3. The probability of an employment status change should therefore be significantly higher for the age 63 than for the others.

\footnotetext{
${ }^{6}$ According to the German partial retirement law (Altersteilzeitgesetz, AltTZG) of 1996, published in BGBl I 1996, p. 1078.

${ }^{7}$ A relatively long transitional period was implemented with these reforms. Therefore, some rules of the old pension system will continue to be effective until 2017.
} 


\section{The data}

The analysis of the employment status of older workers in Germany is based on the Socio-Economic Panel (GSOEP) data for the years 1997 and 2001. ${ }^{8}$ The GSOEP (Haisken-DeNew and Frick, 2003) is a representative longitudinal survey of private households collected by the German Institute for Economic Research (DIW). Annually, since 1984, the same individuals have been asked for the development of their living and working conditions. Since the German reunification in 1990, East German households have been added to the survey.

The data analyzed in this paper were taken from the waves conducted in 1997 and 2001. Those were two of the four years $(1997,1999,2000,2001)$ in which questions concerning computer use were asked. The questions in 1997 and 2001 were: 'Do you use a computer or the Internet in your occupation or training? And if you do so since when?'9 This information is used in a first step to find out who uses computers at work. However, no information is given about what kind of computer is meant. In a second step the impact of computer use on the change of the employment status of older workers in 2001 compared to 1997 depending on whether or not they used a computer in the workplace in 1997 is studied. The employment status of the people analyzed is 'employed full-time' in 1997. In 2001 it can either be still 'employed full-time', or it can change and the people become 'employed part-time' or 'unemployed'10.

The people being analyzed in this paper are males between the ages of 46 and 60 in 1997. By getting an age of 50 to 64 in 2001, this group becomes what is commonly defined as "older workers" (see e.g. Bartel and Sicherman, 1993). Men in their late forties oftentimes already face prejudices from the employers' side concerning

\footnotetext{
${ }^{8}$ The question considering union membership was taken from the year 1998.

${ }^{9}$ The exact questions were: 'Benutzen Sie beruflich - oder in einer Ausbildung - einen Computer und das Internet? Computer: ja $=1$ / nein $=2$, falls 'ja': seit welchem Jahr? Internet: ja $=1$ / nein $=2$, falls 'ja': seit welchem Jahr?' The questions of the years 1999 and 2000 were less precise. In addition, using data of 1997 and 2001 provides the largest possible longitudinal section to be analyzed concerning computer use and changes in employment status. In this study the information about Internet use has been ignored.

${ }^{10}$ This division was chosen under the assumption that for the analyzed older age group parttime employment is a form of smooth transition into retirement.
} 
the productivity of older workers and may have problems to stay in their job. Therefore, the lower threshold of 46 was chosen. Thus, the analyzed dataset also comprises male workers in their fifties who are in certain circumstances allowed to reduce their working time in accordance with various early retirement regulations in Germany (see Section 2.2). The maximum age of 60 in the year 1997 implies that the workers had not yet reached the regular retirement age of 65 in 2001 . The sample is restricted to male persons because only a very small share of women of this age group is working full-time. In addition, only people who responded to the survey questions about their computer use in 1997 are included in the analyses.

The GSOEP wave of the year 1997 covers more than 13,000 individuals aged 16 years and older. According to the group of workers to be analyzed, the sample was restricted to 886 individuals for whom the relevant criteria are fulfilled. For comparison, further analyses additionally include those 1915 men employed fulltime who were younger than 46 years in 1997.

A main limitation of the data is that only little information is given about the reasons for leaving work or being unemployed. We hardly know whether people retire voluntarily or not, or whether they stay unemployed voluntarily or not because only a few of the interviewed people answered the according questions. In addition, there may be a selection bias, as only people who work full-time in 1997 are considered (see Section 4.2), since there is no information on whether or not people who do not work have professional experience with computers.

\section{Results}

\subsection{Descriptive statistics}

This section provides descriptive results on the relationship between computer use and different individual and job-related characteristics of older workers. To offer more insight into the data the results of older workers (46 to 60 years old) are compared to those of the younger ones (17 to 45 years old).

An overall fraction of $47 \%$ of the older workers used a computer at the workplace 
in 1997. This fraction corresponds to that of the men who were younger than 46 years of age (see Table 10 in the Appendix). Table 1 shows some first descriptive statistics of the men employed full-time according to different individual characteristics observed in 1997. Among the group of older German men more than half $(53 \%)$ used a computer on the job, among the group of the foreigners only $13 \%$ did. The difference in the shares of computer use between young German and foreign men was not that high: $51 \%$ of the young Germans but more than $20 \%$ of the young foreigners used a computer.

There was a difference of 11 percentage points in the computer use between older employees living in East and in West Germany (residence in 1990). Whereas $50 \%$ of the West German men used a computer in 1997, nearly $40 \%$ of the East German men did. Among the men younger than 46 the difference between East and West German men was about $8 \%$.

Table 1: Computer use by demographic characteristics*

\begin{tabular}{ccccc}
\hline & \multicolumn{2}{c}{ old $^{* *}$} & \multicolumn{2}{c}{ young $^{* * *}$} \\
& users & non-users & user & non-user \\
\hline $\begin{array}{c}\text { nationality } \\
\text { German }\end{array}$ & 53 & 47 & 51 & 49 \\
Non-German & 13 & 87 & 22 & 78 \\
region & & & & \\
East & 39 & 61 & 42 & 58 \\
West & 50 & 50 & 49 & 51 \\
\hline
\end{tabular}

*) In $\%$.

**) Male workers who were between 46 and 60 years old in 1997.

***) Male workers who were between 17 and 45 years old in 1997.

Source: Author's calculations based on GSOEP 1997.

Example: A share of $47 \%$ of the older German men declared to use a computer on the job.

Table 2 shows the shares of computer users and non-users among different levels of education of the older workers ( 2 of the 886 men gave no details on their educational level). As expected the shares differed a lot between the educational groups. Among those older men who reached primary education or less (ISCED definition) the small share of $6 \%$ declared to use a computer at the workplace (13\% of the younger men), and among those with lower secondary education $8 \%$ 
$(22 \%)$ did. Those older (younger) men with a form of vocational degree (upper secondary education) as their highest level of education (such as an apprenticeship) used a computer with a share of $43 \%$ (42\%). And a high share of $75 \%$ of the older men ( $87 \%$ of the younger) with a tertiary education (such as university degree) stated to use a computer on the job. This positive relationship between education and computer use can often be found in the literature. For example, it is described by Borghans and ter Weel (2002) using data of Germany, Great Britain and the United States.

Table 2: Computer use by highest education level*

\begin{tabular}{lcccc}
\hline & \multicolumn{2}{c}{ old } & \multicolumn{2}{c}{ young } \\
& users & non-users & user & non-user \\
\hline $\begin{array}{c}\text { without any degree } \\
\text { primary school or less }\end{array}$ & 6 & 94 & 13 & 87 \\
lower secondary education & 8 & 92 & 22 & 77 \\
upper secondary education & & & & \\
other vocational education & 20 & 80 & 13 & 87 \\
apprenticeship & 38 & 62 & 37 & 63 \\
specialized vocational school & 48 & 52 & 50 & 50 \\
technical/commercial college & 71 & 29 & 68 & 32 \\
civil servant school & 82 & 18 & 83 & 17 \\
tertiary education & & & & \\
college abroad** & 72 & 20 & 88 & 12 \\
polytechnical & 72 & 20 & 88 & 12 \\
university & 78 & 23 & 90 & 10 \\
\hline
\end{tabular}

*) Notes, Source, Example: see Table 1.

${ }^{* *}$ ) In the data it is not clear what kind of degree is meant.

A share of $14 \%$ of older workers with at most lower secondary education seems to be quite small compared to other studies. For example, according to Herfurth and Kohli (2003, p. 151-152) using German microcensus data, in 2003 among people aged 35 to 45 years a share of nearly $20 \%$ was without a degree and without a vocational degree, but even more than 30\% among the oldest agegroups. However, they consider all people not only men and not only employees, which may explain the difference in the results. 
In order to analyze the occupational status in connection with computer use the workforce is divided into seven status categories. There are blue collar workers, clerical workers and civil servants that are subdivided into low-level jobs and highlevel jobs ${ }^{11}$, and there are self-employed. The distribution of computer users and non-users by occupation is displayed in Table 3. Only a small share of blue collar workers of both age groups used a computer at the workplace (11\% of the older, $18 \%$ of the younger workers). Nearly half of the low-level clerical workers of both age groups declared to use a computer, but about $70 \%$ of the low-level civil servants of both age groups did. The shares of high-level clerical workers and of high-level civil servants were the highest: $81 \%$ of the old and more than $85 \%$ of the young used a computer. Within the group of older self-employed men the share of users was $55 \%$, whereas $63 \%$ of the younger self-employed men were users. On the basis of U.S. data, also Friedberg (2003) shows that the average share of computer users is small among blue-collar workers (25\% or less) and much higher among professionals, managers, and clerical workers (70-80\%).

Table 3: Computer use by occupational group*

\begin{tabular}{lcccc}
\hline & \multicolumn{2}{c}{ old } & \multicolumn{2}{c}{ young } \\
\hline ulue collar low-level & 5 & non-users & user & non-user \\
blue collar high-level & 15 & 95 & 11 & 89 \\
clerical worker low-level & 47 & 85 & 22 & 78 \\
clerical worker high-level & 81 & 53 & 46 & 54 \\
civil servant low-level & 67 & 19 & 85 & 15 \\
civil servant high-level & 81 & 33 & 72 & 28 \\
self-employed & 55 & 19 & 89 & 11 \\
\hline
\end{tabular}

*) Notes, Source, Example: see Table 1.

\footnotetext{
${ }^{11}$ Low-level jobs: unskilled workers, clerical workers with simple tasks, lower or middle grade of the civil service. High-level jobs: skilled workers, foremen, clerical workers with professional tasks and/or executive functions, upper grade of the civil service.
} 
Considering the size of the firms (calculated by the number of employees) where the older employees were working, it can be seen that in 1997 large firms with 2000 or more employees have the highest share of older computer users $(60 \%)$. Among the firms with less than 2000 employees 40 to $45 \%$ of the older workers used a computer on the job. Obviously computer technology was introduced more often in those big firms. This result can also be found by taking a look at the younger employees where the share of computer users $(65 \%)$ was highest in the big firms, as well (Table 4). The research results documented in the 'IKTReport' (ZEW, 2003) support these findings. In the analyses using data of the 'manufacturing sector' and the 'service sector' in 2002 smaller firms declared to take little advantage of ICT applications and to face a shortage in skilled labor. Therefore, small firms are less likely to use ICT.

Table 4: Computer use by firm size*

\begin{tabular}{lcccc}
\hline & \multicolumn{2}{c}{ old } & \multicolumn{2}{c}{ young } \\
& users & non-users & user & non-user \\
\hline less than $\mathbf{5}$ & 44 & 56 & 46 & 54 \\
$\mathbf{5}$ to $\mathbf{1 9}$ & 40 & 60 & 31 & 69 \\
$\mathbf{2 0}$ to $\mathbf{1 9 9}$ & 42 & 58 & 41 & 59 \\
$\mathbf{2 0 0}$ to $\mathbf{1 9 9 9}$ & 45 & 55 & 49 & 51 \\
$\mathbf{2 0 0 0}$ or more & 58 & 42 & 65 & 35 \\
\hline
\end{tabular}

*) Notes, Source, Example: see Table 1.

In order to analyze the relationship between computer use, employment status and the economic sector the employees were working in they are allocated to ten different business areas. The highest shares of computer users can be found in the sector 'credit, insurance, real estate' where employees usually have to handle huge datasets and have to perform complex calculations. $77 \%$ of the older and $96 \%$ of the younger workers of that sector used a computer. As can be expected, also in the sector 'data processing, R\&D, business services' the share of computer users was high. In this sector $69 \%$ of the older and even $85 \%$ of the younger workers were users. Moreover, in the 'public sector' the shares of older and younger workers using a computer were high and nearly the same for both age groups (68\% and 67\%). Except for the sector 'wholesale, retail trade' with $56 \%$ older 
computer users (50\% among the young), all other sectors had less than $46 \%$ users among both age groups. See Table 5 for the sector-specific comparison between the shares of computer users and non-users of older and younger workers.

Table 5: Computer use by economic sector*

\begin{tabular}{lcccc}
\hline & \multicolumn{2}{c}{ old } & \multicolumn{2}{c}{ young } \\
& users & non-users & user & non-user \\
\hline agriculture, forestry, fisheries & 32 & 68 & 21 & 79 \\
production industries & 32 & 68 & 27 & 73 \\
manufacturing & 42 & 58 & 45 & 55 \\
wholesale, retail trade & 56 & 44 & 50 & 50 \\
hotels \& restaurants & 11 & 89 & 27 & 73 \\
transport, communications & 42 & 58 & 37 & 63 \\
credit, insurance, real estate & 77 & 23 & 96 & 4 \\
data processing, R\&D, business & 69 & 31 & 85 & 15 \\
services & 68 & 32 & 67 & 33 \\
public sector & 32 & 68 & 40 & 60 \\
other sectors & & & & \\
\hline
\end{tabular}

*) Notes, Source, Example: see Table 1.

\subsection{Estimating the determinants of computer use}

In this section the determinants of computer use for the sample of older employees in 1997 are analyzed. The hypotheses that in particular age, region, education, and occupation have a significant impact on the probability of using a computer are tested. Descriptive statistics on the estimation sample can be found in Table 11 in the Appendix.

Computer use is measured by a binary variable taking the value 1 if the employee uses a computer and the value 0 if he does not. The impact of the different individual and job-related characteristics on the probability of using a computer is analyzed in three steps. At first, only age dummies are included in the regression. In a second step, individual characteristics (such as region, education, occupational status as well as hourly wage) are added. The third specification additionally includes firm-specific determinants (firm size, industrial sectors). 
As the use of a computer at the workplace is observable for employed people only, the analyzed sample is supposed to be a non-random sample. This may cause a sample selection bias in the estimations. Therefore, instead of using the usual probit model the probit sample selection model including a Heckman correction was used at first. The three estimations including the Heckman correction (additionally using the variables 'marital status' and 'being disabled' in the selection equation) lead to the result that the hypothesis that the correlation coefficient between the error terms of the two model equations $\rho$ equals zero can not be rejected. Thus, no significant dependency of the two equations can be found on the basis of the chosen variables and the estimation of a usual binary probit model without sample selection correction is possible (Verbeek, 2000, p. 208). However, it has to be mentioned that the instruments are weak. Moreover, the hourly wage was not included in the Heckman regression function because of calculation problems.

Assuming that the latent propensity of computer use $y_{i}^{*}$ depends on individual and job-related characteristics $X_{i}$ and on normally distributed unobserved factors $\varepsilon_{i}$ in the form

$$
y_{i}^{*}=X_{i} \beta+\varepsilon_{i}
$$

the observed computer use $y_{i}$ is

$$
y_{i}=\left\{\begin{array}{lll}
1 & \text { if } & y_{i}^{*}>0 \\
0 & \text { if } & y_{i}^{*} \leq 0
\end{array}\right.
$$

and the probability of computer use can be depicted as

$$
\operatorname{Pr}\left(y_{i}=1 \mid X_{i}\right)=\operatorname{Pr}\left(y_{i}^{*}>0 \mid X_{i}\right)=\Phi\left(X_{i} \beta\right)
$$

where $\Phi$ is the cumulative normal distribution function (see e.g. Greene, 2000, p. 818). 
The results of the three probit estimations are presented in Table $6^{12}$. As mentioned above, specification (1) includes only age dummies and it shows that the probability of using a computer at the workplace is lower for workers of all ages between 47 and 60 in 1997 compared to those who are 46 (though not all coefficients are significant). Especially the ages between 54 and 60 show a highly significant effect. This finding supports the hypothesis that computer use is age dependent and that computer use is lower for older workers.

The descriptive statistics in Section 4.1 have shown that the use of computers differs by region (East Germany, West Germany) and by nationality (German, Non-German). In order to find out whether the differences are significant, these two variables are included in specification (2). Many economic studies ascertain a positive relationship between the highest achieved educational level of the workers and their use of new technologies. Therefore, ten education variables are considered additionally in specification (2) to test this presumption on the basis of the GSOEP data. Furthermore, job-related characteristics are included to analyze the impact of the occupational status ( 7 status categories, see page 16 ), of the tenure of the employees as well as of their hourly wage.

Specification (2) in Table 6 leads to increased estimated coefficients for all ages. The age dummies that were insignificant in specification (1) remain insignificant. East German workers are less likely to use a computer than West Germans, although the coefficient is significant only at the $10 \%$ level. In contrast to the results of many other empirical studies (see e.g. Entorf, Gollac, and Kramarz, 1999) and in contrast to the results for workers younger than 46 (see Table 12 in the Appendix), only one of the educational variables shows a significant effect on computer use: older workers without any degree have a significantly smaller probability than those who reached a university degree. All occupational status categories (except that of high-level blue collar jobs) show a significant impact on the probability of using a computer. It is higher for all clerical workers, civil servants and self-employed as compared to blue collar workers. Also the hourly wage shows a significantly positive effect on the probability of using a computer. However, the direction of causality between computer use and wage

\footnotetext{
${ }^{12}$ For comparison the estimation results for men employed full-time who are younger than 46 are given in Table 12 in the Appendix. Descriptive statistics of this sample of younger workers can be found in Table 13 .
} 
is not clear. Borghans and ter Weel (2002), and Entorf and Kramarz (1997) also find the positive correlation between computer use and wage. They conclude that workers who use a computer have already earned higher wages before the introduction of new technologies. Those workers are assumed to have a higher unobserved ability. Computer use will raise their productivity and increase their wages further.

The previous conclusions remain the same after including information on firm size, industrial sector and union membership in specification (3). Firms with less than 20 employees show a negative impact on the probability of using a computer, firms with 200 or more employees a positive one. However, all firm size coefficients are insignificant. Only three of the ten analyzed industries show a significant effect. The workers of the sectors 'manufacturing', of 'wholesale, retail trade' and those of the sector 'data processing, R\&D, business services' have a significantly higher probability of using a computer than workers employed in the 'public sector'. The effect of union membership on the probability of using a computer turns out to be highly significant and positive for older men. This effect is hard to explain, and it is not observable when analyzing the younger age group. 
Table 6: Probit estimation of the determinants of computer use of older workers $^{i}$ in 1997

\begin{tabular}{|c|c|c|c|}
\hline \multicolumn{4}{|c|}{ dependent variable: computer use } \\
\hline variable (reference group) & (1) & $(2)$ & (3) \\
\hline \multicolumn{4}{|l|}{ age (ref.: age 46 ) } \\
\hline age 47 & $-.118(.208)$ & $.053(.289)$ & $.141(.329)$ \\
\hline age 48 & $-.030(.194)$ & $-.087(.268)$ & $-.375(.303)$ \\
\hline age 49 & $-.459(.217)^{* *}$ & $-.474(.291)$ & $-.680(.321)^{* *}$ \\
\hline age 50 & $-.266(.221)$ & $-.315(.316)$ & $-.576(.359)$ \\
\hline age 51 & $-.432(.223)^{*}$ & $-.760(.319)^{* *}$ & $-1.138(.354)^{* * *}$ \\
\hline age 52 & $-.592(.241)^{* *}$ & $-.766(.333)^{* *}$ & $-1.131(.372)^{* * *}$ \\
\hline age 53 & $-.213(.205)$ & $-.216(.285)$ & $-.345(.306)$ \\
\hline age 54 & $-.441(.211)^{* *}$ & $-.507(.284)^{*}$ & $-.859(.313)^{* * *}$ \\
\hline age 55 & $-.500(.223)^{* *}$ & $-.822(.313)^{* * *}$ & $-1.064(.341)^{* * *}$ \\
\hline age 56 & $-.465(.219)^{* *}$ & $-.560(.296)^{*}$ & $-.585(.333)^{*}$ \\
\hline age 57 & $-.511(.214)^{* *}$ & $-.849(.303)^{* * *}$ & $-.982(.334)^{* * *}$ \\
\hline age 58 & $-.473(.221)^{* *}$ & $-.683(.307)^{* *}$ & $-.824(.336)^{* *}$ \\
\hline age 59 & $-.778(.240)^{* * *}$ & $-1.112(.367)^{* * *}$ & $-1.283(.395)^{* * *}$ \\
\hline age 60 & $-.801(.291)^{* * *}$ & $-1.349(.478)^{* * *}$ & $-1.570(.504)^{* * *}$ \\
\hline \multicolumn{4}{|l|}{ nationality (ref.: foreign) } \\
\hline German & & $.177(.296)$ & $.244(.326)$ \\
\hline \multicolumn{4}{|l|}{ region (ref.: west) } \\
\hline east & & $-.321(.173)^{*}$ & $-.355(.193)^{*}$ \\
\hline \multicolumn{4}{|c|}{ education (ref.: university degree) } \\
\hline primary school or less & & $-.610(.585)$ & $-.742(.647)$ \\
\hline lower secondary education & & $-.984(.388)^{* *}$ & $-1.145(.419)^{* * *}$ \\
\hline other vocational education & & $-.165(.387)$ & $-.191(.421)$ \\
\hline apprenticeship & & $-.036(.237)$ & $-.178(.260)$ \\
\hline special. vocational school & & $-.106(.274)$ & $-.412(.302)$ \\
\hline technical school & & $.205(.304)$ & $.080(.325)$ \\
\hline civil servant school & & $.244(.397)$ & $-.115(.413)$ \\
\hline polytechnical & & $.021(.239)$ & $-.091(.261)$ \\
\hline college abroad & & $.129(.563)$ & $.604(.691)$ \\
\hline \multicolumn{4}{|c|}{ occup. status (ref.: blue collar low-l.) } \\
\hline blue collar high-level & & $.258(.239)$ & $.393(.261)$ \\
\hline clerical worker low-level & & $1.215(.291)^{* * *}$ & $1.713(.335)^{* * *}$ \\
\hline clerical worker high-level & & $2.065(.256)^{* * *}$ & $2.566(.300)^{* * *}$ \\
\hline civil servant low-level & & $1.329(.408)^{* * *}$ & $1.964(.479)^{* * *}$ \\
\hline civil servant high-level & & $1.847(.377)^{* * *}$ & $2.713(.446)^{* * *}$ \\
\hline self-employed & & $1.483(.276)^{* * *}$ & $2.251(.450)^{* * *}$ \\
\hline
\end{tabular}


Table 6: continued table

\begin{tabular}{|c|c|c|c|}
\hline variable (reference group) & (1) & $(2)$ & (3) \\
\hline tenure & & $-.019(.020)$ & $-.037(.023)$ \\
\hline tenure $^{2} *(1 / 100)$ & & $.046(.051)$ & $.083(.058)$ \\
\hline log hourly wage & & $.514(.177)^{* * *}$ & $.427(.200)^{* *}$ \\
\hline \multicolumn{4}{|c|}{ firm size (ref.: 20 to 199 employees) } \\
\hline less than 5 & & & $-.190(.399)$ \\
\hline 5 to 19 & & & $-.103(.263)$ \\
\hline 200 to 1999 & & & $.159(.188)$ \\
\hline 2000 or more & & & $.167(.190)$ \\
\hline \multicolumn{4}{|l|}{ industry (ref.: public sector) } \\
\hline agriculture, forestry, fisheries & & & $.416(.498)$ \\
\hline production industries & & & $.238(.250)$ \\
\hline manufacturing & & & $.808(.229)^{* * *}$ \\
\hline wholesale, retail trade & & & $.931(.323)^{* * *}$ \\
\hline transport, communications & & & $.129(.298)$ \\
\hline credit, insurance, real estate & & & $.503(.365)$ \\
\hline $\begin{array}{l}\text { data processing, R\&D, } \\
\text { business services }\end{array}$ & & & $.893(.429)^{* *}$ \\
\hline other sectors & & & $.281(.352)$ \\
\hline union membership & & & $.533(.166)^{* * *}$ \\
\hline constant & $.266(.141)^{*}$ & $-2.177(.744)^{* * *}$ & $-2.577(.863)^{* * *}$ \\
\hline Pseudo-R $^{2}$ & .024 & .425 & .472 \\
\hline number of observations & 886 & 749 & 705 \\
\hline
\end{tabular}

Notes: ${ }^{* *},{ }^{* *}, *$ depicts significance at the $1 \%, 5 \%$ and $10 \%$ level. Standard errors in parentheses. $\left.{ }^{i}\right)$ Men who were between 46 and 60 years old in 1997 .

The sector 'hotels \& restaurants' has to be omitted as all workers of that sector who were included in the regression are non-users.

Source: Author's calculations based on GSOEP 1997 and 1998. 


\subsection{Estimating the impact of computer use on the em- ployment status change}

In order to get rid of unobserved heterogeneity the main hypothesis to be tested in this subsection is that older workers who use a computer are more likely to remain employed full-time than non-users of that age group. Therefore the impact of computer use on the change in employment status of male workers between 1997 and 2001 is analyzed. The workers in the dataset were all employed full-time in 1997. In 2001 they were either still full-time workers or they had changed their status and became employed part-time or unemployed (see Table 7). The focus of the analysis lies on the risk of older workers to be urged into early retirement or unemployment, especially if they do not adopt new technologies. The given definition of employment change concerning part-time workers is chosen as in the analysis the change of older workers from full-time into part-time employment is assumed to be a (voluntary or involuntary) decision for a transitional status before definitely going into retirement. This assumption is supported by the finding that three quarters of the part-time workers were between 60 and 64 years old (see Table 7$)^{13}$. Men who declared to be unemployed but not looking for a new job are defined as 'retired'14.

\footnotetext{
${ }^{13}$ To accentuate the role of the workers' age when considering the change in employment status the age in 2001 is used in the further analyses.

${ }^{14}$ The recipiency of pension or Social Security income was not considered when defining retirement.
} 
Table 7: Employment status of older workers* in 2001 by age group (quantities)

\begin{tabular}{|c|c|c|c|c|}
\hline \multirow{2}{*}{ employment status } & \multicolumn{3}{|c|}{ age group } & \multirow{2}{*}{ total } \\
\hline & 50 to 54 & 55 to 59 & 60 to 64 & \\
\hline employed full-time & 319 & 219 & 107 & 645 \\
\hline employed part-time & 3 & 3 & 18 & 24 \\
\hline not employed (retired) & 5 & 25 & 88 & 118 \\
\hline not employed (looking for a job) ${ }^{* *}$ & 26 & 39 & 34 & 99 \\
\hline overall & 353 & 286 & 247 & 886 \\
\hline
\end{tabular}

Notes: *) Men who were employed full-time and between 50 and 64 years old in 2001.

**) Including two men who declared to be retired.

Source: Author's calculations based on GSOEP 1997 and 2001.

Example: In 2001, three fourths (18 men) of the older male employees who declared to work part-time were between 60 and 64 years old.

In Table 8, a first hint about employment status differences between older computer users and non-users is given. Among the 473 non-users $32 \%$ have changed the status between 1997 and 2001, 68\% have not. Among the 413 users the higher share of nearly $80 \%$ was still employed full-time in 2001 . However, according to Friedberg (2003) who uses a different definition of changes in the employment status, computer users seem to be less likely to retire than non-users. 
Table 8: Employment status of older computer users and non-users* in 2001

\begin{tabular}{|c|c|c|c|c|}
\hline \multirow{2}{*}{ employment status } & \multicolumn{2}{|c|}{ users } & \multicolumn{2}{|c|}{ non-users } \\
\hline & quantity & in $\%$ & quantity & in $\%$ \\
\hline employed full-time & 325 & 79 & 320 & 68 \\
\hline employed part-time & 10 & 2 & 14 & 3 \\
\hline not employed (retired) & 47 & 11 & 71 & 15 \\
\hline not employed (looking for a job) ${ }^{* *}$ & 31 & 8 & 68 & 14 \\
\hline overall & 413 & 100 & 473 & 100 \\
\hline
\end{tabular}

Notes: $\left.{ }^{*}\right)$ Men who were employed full-time and between 50 and 64 years old in 2001.

$\left.{ }^{* *}\right)$ Including two men who declared to be retired.

Source: Author's calculations based on GSOEP 1997 and 2001.

Example: Nearly $80 \%$ (325 men) of the older male employees who declared to use a computer on the job did not change their employment status between 1997 and 2001 and remained employed full-time.

In a next step, the impact of computer use on the development of the employment status of the older workers between 1997 and 2001 will be taken into account in a multivariate estimation. Here, the latter is measured by a dummy variable $z$. It takes the value 0 if workers had the same (full-time) status in 1997 and in 2001. For workers who changed their employment status to being employed part-time, retired or unemployed (and looking for a job) in 2001, the value of $z$ is 1 . As the status variable $z$ has two possible outcomes the binary probit model is used, including further control variables. ${ }^{15}$

\footnotetext{
${ }^{15}$ As the sample size is not that large and there are a lot of control variables included in the regression the multinomial logit model could not be applied.
} 
Table 9: Probit estimation of the employment status change of older workers $^{i}$ between 1997 and 2001

\begin{tabular}{|c|c|c|c|c|}
\hline \multicolumn{5}{|c|}{ dependent variable: change in employment status } \\
\hline variable (reference group) & (1) & $(2)$ & (3) & $(4)$ \\
\hline computer use & $-.338(.092)^{* * *}$ & $-.254(.101)^{*}$ & $-.057(.161)$ & $.010(.174)$ \\
\hline \multicolumn{5}{|l|}{ age (ref.: age 50) } \\
\hline age51 & & $-.075(.290)$ & $.106(.353)$ & $.239(.395)$ \\
\hline age 52 & & $.060(.260)$ & $.027(.341)$ & $.197(.382)$ \\
\hline age53 & & $-.024(.294)$ & $.259(.338)$ & $.452(.375)$ \\
\hline age54 & & $-.186(.321)$ & $-.164(.401)$ & $.074(.438)$ \\
\hline age55 & & $.127(.292)$ & $.592(.346)^{*}$ & $.801(.386)^{* *}$ \\
\hline age56 & & $.254(.300)$ & $.528(.355)$ & $.831(.393)^{* *}$ \\
\hline age 57 & & $.570(.252)^{*}$ & $.720(.313)^{* *}$ & $.954(.353)^{* * *}$ \\
\hline age 58 & & $.234(.270)$ & $.433(.324)$ & $.614(.361)^{*}$ \\
\hline age59 & & $1.207(.257)^{* * *}$ & $1.379(.317)^{* * *}$ & $1.655(.362)^{* * *}$ \\
\hline age60 & & $1.234(.255)^{* * *}$ & $1.391(.309)^{* * *}$ & $1.693(.359)^{* * *}$ \\
\hline age61 & & $1.293(.250)^{* * *}$ & $1.575(.310)^{* * *}$ & $1.988(.356)^{* * *}$ \\
\hline age62 & & $1.813(.263)^{* * *}$ & $2.274(.337)^{* * *}$ & $2.620(.384)^{* * *}$ \\
\hline age63 & & $1.393(.269)^{* * *}$ & $1.597(.341)^{* * *}$ & $1.900(.385)^{* * *}$ \\
\hline age64 & & $1.364(.309)^{* * *}$ & $-1.783(.398)^{* * *}$ & $2.232(.450)^{* * *}$ \\
\hline nationality & & & yes $^{i i}$ & yes \\
\hline region & & & yes & yes \\
\hline marital status & & & yes & yes \\
\hline education & & & yes & yes \\
\hline \multicolumn{5}{|c|}{ occup. status (ref.: blue collar low-l.) } \\
\hline blue collar high-level & & & $.306(.185)^{*}$ & $.336(.198)^{*}$ \\
\hline clerical worker low-level & & & $-.039(.283)$ & $-.027(.304)$ \\
\hline clerical worker high-level & & & $-.246(.254)$ & $-.248(.277)$ \\
\hline civil servant low-level & & & $.698(.405)^{*}$ & $.648(.463)$ \\
\hline civil servant high-level & & & $-.340(.399)$ & $-.146(.465)$ \\
\hline self-employed & & & $-.763(.297)^{* * *}$ & $-1.544(.447)^{* * *}$ \\
\hline tenure & & & $-.015(.020)$ & $.001(.022)$ \\
\hline tenure $^{2} *(1 / 100)$ & & & $.057(.049)$ & $.009(.053)$ \\
\hline log hourly wage & & & $-.204(.206)$ & $-.109(.228)$ \\
\hline firm size & & & & yes $^{i i}$ \\
\hline
\end{tabular}

continued next page 
Table 9: continued table

\begin{tabular}{|c|c|c|c|c|}
\hline variable (reference group) & (1) & $(2)$ & (3) & (4) \\
\hline \multicolumn{5}{|l|}{ industry (ref.: public sector) } \\
\hline agriculture, forestry, fisheries & & & & $1.341(.448)^{* * *}$ \\
\hline production industries & & & & $.484(.251)^{*}$ \\
\hline manufacturing & & & & $.411(.236)^{*}$ \\
\hline wholesale, retail trade & & & & $.381(.334)$ \\
\hline hotels \& restaurants & & & & $1.141(.726)$ \\
\hline transport, communications & & & & $.581(.303)^{*}$ \\
\hline credit, insurance, real estate & & & & $.354(.394)$ \\
\hline $\begin{array}{l}\text { data processing, } R \& D \text {, business } \\
\text { services }\end{array}$ & & & & $.493(.417)$ \\
\hline other sectors & & & & $.463(.343)$ \\
\hline constant & $-.458(.060)^{* * *}$ & $-1.150(.199)^{* * *}$ & $-1.180(.804)^{* * *}$ & $-2.229(.920)^{* *}$ \\
\hline Pseudo-R ${ }^{2}$ & .013 & .193 & .263 & .294 \\
\hline number of observations & 886 & 886 & 749 & 721 \\
\hline
\end{tabular}

Notes: $* * *, * *, *$ depicts significance at the $1 \%, 5 \%$ and $10 \%$ level. Standard errors in parentheses.

i) Men who were between 46 and 60 years old in 1997 .

${ }^{i i}$ ) yes $=$ included in the specification but insignificant coefficients.

Source: Author's calculations based on GSOEP 1997 and 2001.

Table 9 shows four probit regression specifications for the analysis of the impact of computer use on the employment status of older workers. In the first specification only computer use is included to see the bivariate correlation. There is a negative and highly significant effect on the probability of changing the employment status. Thus, computer users seem to be more likely to remain employed full-time than non-users. A less significant effect persists if age dummies (for every age between 51 and 64 in 2001) are included (2). However, the significant effect of computer use on the employment status change of older workers vanishes when including some more individual characteristics, such as nationality (German, Non-German), education, occupational status and log hourly wages (3). The effect of computer use remains insignificant when additionally controlling for firm-related variables, such as firm size and industrial sector (4). These results corroborate similar findings by Aubert et al. (2004) who show that computer use has no differential impact regarding employment outflows.

Specification (4) indicates that the occupational status of workers (self-employed 
or not) and the industrial sector they were working in are more important for the probability of changing the employment status between 1997 and 2001 than computer use. Self-employed men are significantly less likely to become part-time employed or unemployed than other kinds of workers. This result is not surprising as self-employed men are not eligible for retirement pension the way employees are. They have a big incentive to work longer as well as to work full-time in order to finance their life. Moreover, they cannot be dismissed by an employer for any reason. Being a high-level blue collar worker shows a less significant and positive effect.

In addition, workers operating in the sector 'agriculture, forestry, fishing' have a significantly higher probability of changing the employment status than employees in the public sector. Those who change their status are mostly unemployed and looking for a job. This may reflect the bad labor market situation in this sector, although it has to be mentioned that in the analyzed sample of 1997 there were only 16 older men working in the agricultural sector. Besides 'agriculture' only being employed in one of the sectors 'production industries', 'manufacturing' or 'transport, communications' has small significant and positive effects on the probability of changing the status. Thus, employees working in the public sector seem to be somewhat less likely to change their employment status after controlling for all the other variables. This may be due to extensive dismissal protection regulations in that sector, in particular concerning older workers.

From age 55 on the probability of changing the employment status is significantly positively affected by age. The impact increases with age. This finding is straightforward as more and more workers of the analyzed age group retire when they get older. However, the age coefficients do not show any pattern consistent with age thresholds given by legal possibilities of early retirement. Besides the described characteristics all other variables considered in specification (4) show no significant impact on the probability of changing the employment status.

The results of the estimations differ from those given by Friedberg (2003). She finds a significant effect of computer use on the retirement decision even after including other covariates. People who use a computer at the workplace choose to retire later. However, Friedberg uses a slightly different definition of the change in employment status and analyzes male and female workers. 
Also Bartel and Sicherman (1993) describe the effects of various variables on the retirement decision. For example, self-employed workers retire later. This result is similar to the one given in this paper. On the other hand they find that schooling has a negative effect on the likelihood of retirement, tenure has a positive one, and government employees choose to retire earlier. In contrast, the effects of education and tenure are insignificant in specification (4) of the employment status regression of this paper. However, workers of the public sector show a higher probability of staying employed full-time, in concordance with the results of Bartel and Sicherman (1993).

\section{Concluding remarks}

Older workers are often assumed not to be able to keep pace with younger workers in adopting and using new technologies. Besides the existence of this skill lag the time to capture the returns to older worker's training investment is assumed to be short. Thus, the incentive to invest in training may be lower for both older workers themselves and their employers. This may be an important reason why employers try to substitute older workers by deploying younger ones and use the possibilities of early retirement. This paper attempts to analyze descriptively as well as econometrically the relationship between computer use and the employment status of older workers. It analyzes the characteristics of computer users and whether or not they have a higher probability of remaining employed fulltime. For this purpose individual data of the German SOEP 1997 and 2001 of male workers over 45 years old are used.

As presumed, the age of workers has a significant impact on the probability of using a computer on the job. It is negative and therefore implies a declining probability of computer use by the workers' age, even after controlling for many other variables.

In many other studies (e.g. Friedberg, 2003, Entorf et al., 1999) it is stated that the educational level has an important influence on the probability of using a computer. The higher the level of education of workers, the higher the extent of computer use on the job. The analyzed sample of older workers in this paper does not show this relationship when simultaneously considering educational level and 
occupational status, however. The effects of the educational levels turn out to be insignificant. More important is the impact of the occupational status of older workers. All but high-level blue collar workers (insignificant) show a significantly positive effect on the probability of using a computer compared to low-level blue collar workers. The effect is higher for high-level clerical workers and high-level civil servants than for low-level clerical workers and civil servants.

Further analyses focus on the question whether computer use has a significant impact on the employment status of older workers. In this study, the employment status of older computer users and non-users in 1997 is compared to that of 2001. Descriptive statistics show that computer non-users have a higher probability of changing their employment status from full-time employment to part-time employment, retirement or unemployment. The bivariate correlation between computer use and employment status leads to the same result. However, further estimations show that the extent of the impact of computer use declines after including several individual and firm-related characteristics and finally becomes insignificant. The analyses based on the GSOEP data thus do not support the hypothesis that computer use on the job increases older workers' probability of remaining employed full-time up to the regular retirement age. Their occupational status and the sector they are working in appear to be more important. 


\section{Appendix}

Table 10: Descriptive statistics I

\begin{tabular}{|c|c|c|}
\hline & \multicolumn{2}{|c|}{ Percentage in survey } \\
\hline & $\begin{array}{c}\text { old } \\
(886 \text { men })\end{array}$ & $\begin{array}{c}\text { young } \\
\text { (1915 men) }\end{array}$ \\
\hline computer user & 47 & 47 \\
\hline \multicolumn{3}{|l|}{ age } \\
\hline $17-20$ & & 1 \\
\hline $21-25$ & & 9 \\
\hline $26-30$ & & 21 \\
\hline $31-35$ & & 27 \\
\hline $36-40$ & & 24 \\
\hline $41-45$ & & 19 \\
\hline 46 & 9 & \\
\hline 47 & 8 & \\
\hline 48 & 10 & \\
\hline 49 & 7 & \\
\hline 50 & 6 & \\
\hline 51 & 6 & \\
\hline 52 & 5 & \\
\hline 53 & 8 & \\
\hline 54 & 7 & \\
\hline 55 & 6 & \\
\hline 56 & 6 & \\
\hline 57 & 7 & \\
\hline 58 & 6 & \\
\hline 59 & 5 & \\
\hline 60 & 3 & \\
\hline \multicolumn{3}{|l|}{ nationality } \\
\hline German & 85 & 86 \\
\hline foreign & 15 & 14 \\
\hline \multicolumn{3}{|l|}{ region } \\
\hline east & 28 & 28 \\
\hline west & 72 & 72 \\
\hline
\end{tabular}


Table 10: continued table

\begin{tabular}{|c|c|c|}
\hline & \multicolumn{2}{|c|}{ Percentage in survey } \\
\hline & $\begin{array}{c}\text { old } \\
(886 \text { men })\end{array}$ & $\begin{array}{c}\text { young } \\
(1915 \text { men })\end{array}$ \\
\hline \multicolumn{3}{|l|}{ education } \\
\hline primary school or less & 4 & 2 \\
\hline lower second. education & 10 & 11 \\
\hline other vocational educ. & 7 & 6 \\
\hline apprenticeship & 34 & 47 \\
\hline special. vocational school & 9 & 6 \\
\hline technical school & 7 & 7 \\
\hline civil servant school & 3 & 3 \\
\hline polytechnical & 1 & 1 \\
\hline university & 10 & 6 \\
\hline college abroad & 15 & 11 \\
\hline \multicolumn{3}{|l|}{ occupational status } \\
\hline blue collar low-level & 17 & 17 \\
\hline blue collar high-level & 25 & 33 \\
\hline clerical worker low-level & 6 & 6 \\
\hline clerical worker high-level & 31 & 28 \\
\hline civil servant low-level & 2 & 4 \\
\hline civil servant high-level & 8 & 3 \\
\hline self-employed & 13 & 10 \\
\hline \multicolumn{3}{|l|}{ firm size ( $\sharp$ of employees) } \\
\hline less than 5 & 12 & 12 \\
\hline 5 to 19 & 12 & 18 \\
\hline 20 to 199 & 29 & 26 \\
\hline 200 to 1999 & 23 & 20 \\
\hline 2000 or more & 24 & 24 \\
\hline \multicolumn{3}{|l|}{ industry } \\
\hline agriculture, forestry, fisheries & 2 & 2 \\
\hline production industries & 19 & 20 \\
\hline manufacturing & 34 & 32 \\
\hline wholesale, retail trade & 6 & 11 \\
\hline hotels \& restaurants & 1 & 1 \\
\hline transport, communications & 8 & 7 \\
\hline credit, insurance, real estate & 4 & 4 \\
\hline $\begin{array}{l}\text { data processing, R\&D, } \\
\text { business services }\end{array}$ & 4 & 5 \\
\hline public sector & 17 & 14 \\
\hline other sectors & 5 & 4 \\
\hline union membership & 31 & 23 \\
\hline
\end{tabular}

Source: Author's calculations based on GSOEP 1997 and 1998. 
Table 11: Descriptive statistics II (Probit estimation of the determinants of computer use of older workers ${ }^{i}$ in 1997)

\begin{tabular}{|c|c|c|c|c|c|c|}
\hline \multirow[t]{2}{*}{ specification } & \multicolumn{2}{|c|}{ (1) } & \multicolumn{2}{|c|}{ (2) } & \multicolumn{2}{|c|}{ (3) } \\
\hline & Mean & St.Dev. & Mean & St.Dev. & Mean & St.Dev. \\
\hline computer use & .466 & .499 & .449 & .497 & .457 & .499 \\
\hline age47 & .077 & .266 & .076 & .265 & .078 & .268 \\
\hline age48 & .103 & .304 & .096 & .295 & .092 & .290 \\
\hline age49 & .067 & .250 & .071 & .257 & .071 & .257 \\
\hline age50 & .061 & .239 & .061 & .240 & .061 & .240 \\
\hline age51 & .060 & .237 & .057 & .233 & .055 & .229 \\
\hline age52 & .049 & .215 & .052 & .222 & .055 & .229 \\
\hline age53 & .080 & .272 & .079 & .270 & .081 & .273 \\
\hline age54 & .073 & .261 & .079 & .270 & .081 & .273 \\
\hline age 55 & .061 & .239 & .064 & .245 & .067 & .250 \\
\hline age 56 & .064 & .246 & .071 & .257 & .067 & .250 \\
\hline age 57 & .070 & .255 & .072 & .259 & .072 & .259 \\
\hline age 58 & .062 & .241 & .063 & .243 & .062 & .242 \\
\hline age59 & .052 & .222 & .044 & .205 & .044 & .205 \\
\hline age60 & .031 & .172 & .025 & .157 & .026 & .158 \\
\hline German & & & .832 & .374 & .834 & .372 \\
\hline east & & & .286 & .452 & .288 & .453 \\
\hline primary school or less & & & .045 & .208 & .045 & .208 \\
\hline lower second. education & & & .099 & .299 & .099 & .299 \\
\hline other vocational educ. & & & .079 & .270 & .078 & .268 \\
\hline apprenticeship & & & .353 & .478 & .356 & .479 \\
\hline special. vocational school & & & .088 & .284 & .084 & .277 \\
\hline technical school & & & .061 & .240 & .064 & .245 \\
\hline civil servant school & & & .033 & .180 & .034 & .181 \\
\hline polytechnical & & & .099 & .299 & .096 & .295 \\
\hline college abroad & & & .013 & .115 & .011 & .106 \\
\hline
\end{tabular}

continued next page 
Table 11: continued table

\begin{tabular}{|c|c|c|c|c|c|c|}
\hline \multirow[t]{2}{*}{ specification } & \multicolumn{2}{|c|}{ (1) } & \multicolumn{2}{|c|}{ (2) } & \multicolumn{2}{|c|}{ (3) } \\
\hline & Mean & St.Dev. & Mean & St.Dev. & Mean & St.Dev. \\
\hline blue collar high-level & & & .268 & .443 & .262 & .440 \\
\hline clerical worker low-level & & & .063 & .243 & .064 & .245 \\
\hline clerical worker high-level & & & .307 & .462 & .313 & .464 \\
\hline civil servant low-level & & & .024 & .153 & .023 & .149 \\
\hline civil servant high-level & & & .064 & .245 & .068 & .252 \\
\hline self-employed & & & .091 & .287 & .084 & .277 \\
\hline tenure & & & 17.836 & 11.615 & 17.953 & 11.572 \\
\hline tenure $^{2} *(1 / 100)$ & & & 4.529 & 4.492 & 4.560 & 4.472 \\
\hline log hourly wage & & & 2.976 & .455 & 2.988 & .449 \\
\hline less than 5 employees & & & & & .084 & .277 \\
\hline 5 to 19 employees & & & & & 113 & .317 \\
\hline 200 to 1999 employees & & & & & .252 & .435 \\
\hline 2000 or more employees & & & & & .252 & .435 \\
\hline agriculture, forestry, fisheries & & & & & .023 & .149 \\
\hline production industries & & & & & 183 & .387 \\
\hline manufacturing & & & & & .366 & .482 \\
\hline wholesale, retail trade & & & & & .065 & .247 \\
\hline transport, communications & & & & & .074 & .262 \\
\hline credit, insurance, real estate & & & & & .034 & .181 \\
\hline data processing, $\mathrm{R} \& \mathrm{D}$, & & & & & & \\
\hline business services & & & & & .037 & .189 \\
\hline other sectors & & & & & .041 & .199 \\
\hline union membership & & & & & .349 & .477 \\
\hline number of observations & & 86 & & 49 & & 05 \\
\hline
\end{tabular}

Notes: ${ }^{i}$ ) Men who were between 46 and 60 years old in 1997.

The sector 'hotels \& restaurants' has to be omitted as all workers of that sector who were included in the regression are non-users.

Source: Author's calculations based on GSOEP 1997 and 1998. 
Table 12: Probit estimation of the computer use of younger workers ${ }^{i}$ in 1997

\begin{tabular}{|c|c|c|c|}
\hline \multicolumn{4}{|c|}{ dependent variable: computer use } \\
\hline variable (reference group) & (1) & $(2)$ & (3) \\
\hline \multicolumn{4}{|l|}{ age (ref.: age $17-20$ ) } \\
\hline $21-25$ & $.627(.442)$ & $.477(.553)$ & $.277(.561)$ \\
\hline $26-30$ & $.816(.435)^{*}$ & $.361(.547)$ & $.253(.552)$ \\
\hline $31-35$ & $.950(.434)^{* *}$ & $.187(.548)$ & $.127(.554)$ \\
\hline $36-40$ & $.946(.435)^{* *}$ & $.079(.550)$ & $.087(.556)$ \\
\hline $41-45$ & $.999(.436)^{* *}$ & $.156(.553)$ & $.114(.559)$ \\
\hline \multicolumn{4}{|l|}{ nationality (ref.: foreign) } \\
\hline German & & $.306(.126)^{* *}$ & $.316(.135)^{* *}$ \\
\hline \multicolumn{4}{|l|}{ region (ref.: west) } \\
\hline east & & $-.026(.096)$ & $.055(.104)$ \\
\hline \multicolumn{4}{|l|}{ education (ref.: university) } \\
\hline primary school or less & & $-1.208(.373)^{* * *}$ & $-1.149(.391)^{* * *}$ \\
\hline lower second. education & & $-.952(.210)^{* * *}$ & $-1.027(.234)^{* * *}$ \\
\hline other vocational educ. & & $-1.284(.247)^{* * *}$ & $-1.325(.267)^{* * *}$ \\
\hline apprenticeship & & $-.753(.173)^{* * *}$ & $-.855(.197)^{* * *}$ \\
\hline special. vocational school & & $-.666(.209)^{* * *}$ & $-.788(.230)^{* * *}$ \\
\hline technical school & & $-.245(.211)$ & $-.173(.235)$ \\
\hline civil servant school & & $-.408(.308)$ & $-.564(.330)^{*}$ \\
\hline polytechnical & & $-.013(.233)$ & $-.054(.257)$ \\
\hline college abroad & & $-1.143(.446)^{* * *}$ & $-1.218(.462)^{* * *}$ \\
\hline \multicolumn{4}{|c|}{ occup. status (ref.: blue collar low-l.) } \\
\hline blue collar high-level & & $.176(.123)$ & $.351(.133)^{* * *}$ \\
\hline clerical worker low-level & & $.804(.170)^{* * *}$ & $.872(.183)^{* * *}$ \\
\hline clerical worker high-level & & $1.640(.139)^{* * *}$ & $1.669(.154)^{* * *}$ \\
\hline civil servant low-level & & $1.249(.243)^{* * *}$ & $1.228(.279)^{* * *}$ \\
\hline civil servant high-level & & $1.852(.337)^{* * *}$ & $1.944(.372)^{* * *}$ \\
\hline self-employed & & $1.286(.159)^{* * *}$ & $1.754(.220)^{* * *}$ \\
\hline
\end{tabular}


Table 12: continued table

\begin{tabular}{|c|c|c|c|}
\hline variable (reference group) & (1) & $(2)$ & (3) \\
\hline tenure & & $.007(.018)$ & $-.019(.020)$ \\
\hline tenure $^{2} *(1 / 100)$ & & $.002(.074)$ & $.081(.080)$ \\
\hline log hourly wage & & $.517(.121)^{* * *}$ & $.263(.133)^{* *}$ \\
\hline \multicolumn{4}{|c|}{ firm size (ref.: 20 to 199 employees) } \\
\hline less than 5 & & & $-.294(.187)$ \\
\hline 5 to 19 & & & $-.314(.131)^{* *}$ \\
\hline 200 to 1999 & & & $.141(.117)$ \\
\hline 2000 or more & & & $.421(.121)^{* * *}$ \\
\hline \multicolumn{4}{|l|}{ industry (ref.: public sector) } \\
\hline agriculture, forestry, fisheries & & & $-.828(.366)^{* *}$ \\
\hline production industries & & & $-.316(.158)^{* *}$ \\
\hline manufacturing & & & $.183(.148)$ \\
\hline wholesale, retail trade & & & $.306(.170)^{*}$ \\
\hline hotels \& restaurants & & & $-.402(.418)$ \\
\hline transport, communications & & & $-.163(.190)$ \\
\hline credit, insurance, real estate & & & $.992(.331)^{* * *}$ \\
\hline \multicolumn{4}{|l|}{ data processing, R\&D, } \\
\hline business services & & & $.903(.261)^{* * *}$ \\
\hline other sectors & & & $-.138(.247)$ \\
\hline union membership & & & $.109(.099)$ \\
\hline constant & $-.967(.431)^{* *}$ & $-2.214(.679)^{* * *}$ & $-1.507(.719)^{* *}$ \\
\hline Pseudo-R $^{2}$ & .007 & .347 & .397 \\
\hline number of observations & 1915 & 1677 & 1607 \\
\hline
\end{tabular}

Notes: ***,**,* depicts significance at the $1 \%, 5 \%$ and $10 \%$ level. Standard errors in parentheses.

$\left.{ }^{i}\right)$ Men who were less than 46 years old in 1997.

${ }^{i i}$ ) yes $=$ included in the specification but no significant coefficients.

Source: Author's calculations based on GSOEP 1997 and 1998. 
Table 13: Descriptive statistics III (Probit estimation of the determinants of computer use of younger workers ${ }^{i}$ in 1997)

\begin{tabular}{|c|c|c|c|c|c|c|}
\hline \multirow[t]{2}{*}{ specification } & \multicolumn{2}{|c|}{ (1) } & \multicolumn{2}{|c|}{ (2) } & \multicolumn{2}{|c|}{ (3) } \\
\hline & Mean & St.Dev. & Mean & St.Dev. & Mean & St.Dev. \\
\hline computer use & .472 & .499 & .464 & .499 & .469 & .499 \\
\hline $21-25$ & .088 & .284 & .088 & .284 & .087 & .282 \\
\hline $26-30$ & .208 & .406 & .209 & .407 & .209 & .407 \\
\hline $31-35$ & .268 & .443 & .270 & .444 & .269 & .444 \\
\hline $36-40$ & .242 & .429 & .239 & .426 & .239 & .427 \\
\hline $41-45$ & .188 & .390 & .189 & .392 & .189 & .392 \\
\hline German & & & .859 & .349 & .861 & .346 \\
\hline east & & & .271 & .445 & .271 & .445 \\
\hline primary school or less & & & .020 & .141 & .021 & .142 \\
\hline lower secondary education & & & .111 & .314 & .110 & .313 \\
\hline other vocational educ. & & & .056 & .230 & .057 & .232 \\
\hline apprenticeship & & & .475 & .500 & .473 & .499 \\
\hline special. vocational school & & & .062 & .241 & .064 & .245 \\
\hline technical school & & & .071 & .257 & .072 & .259 \\
\hline civil servant school & & & .033 & .178 & .032 & .175 \\
\hline polytechnical & & & .061 & .240 & .062 & .242 \\
\hline college abroad & & & .007 & .084 & .007 & .083 \\
\hline blue collar high-level & & & .345 & .475 & .349 & .477 \\
\hline clerical worker low-level & & & .058 & .235 & .058 & .234 \\
\hline clerical worker high-level & & & .273 & .446 & .274 & .446 \\
\hline civil servant low-level & & & .036 & .187 & .035 & .185 \\
\hline civil servant high-level & & & .032 & .177 & .032 & .177 \\
\hline self-employed & & & .082 & .274 & .080 & .272 \\
\hline tenure & & & 7.604 & 6.678 & 7.650 & 6.700 \\
\hline tenure $^{2} *(1 / 100)$ & & & 1.024 & 1.643 & 1.034 & 1.649 \\
\hline log hourly wage & & & 2.875 & .397 & 2.878 & .397 \\
\hline
\end{tabular}

continued next page 
Table 13: continued table

\begin{tabular}{|c|c|c|c|c|c|c|}
\hline \multirow[t]{2}{*}{ specification } & \multicolumn{2}{|c|}{ (1) } & \multicolumn{2}{|c|}{ (2) } & \multicolumn{2}{|c|}{ (3) } \\
\hline & Mean & St.Dev. & Mean & St.Dev. & Mean & St.Dev. \\
\hline less than 5 employees & & & & & .103 & .304 \\
\hline 5 to 19 employees & & & & & .177 & .382 \\
\hline 200 to 1999 employees & & & & & .211 & .408 \\
\hline 2000 or more employees & & & & & .245 & .430 \\
\hline agriculture, forestry, fisheries & & & & & .017 & .129 \\
\hline production industries & & & & & .206 & .405 \\
\hline manufacturing & & & & & .341 & .474 \\
\hline wholesale, retail trade & & & & & .101 & .302 \\
\hline hotels \& restaurants & & & & & .010 & .099 \\
\hline transport, communications & & & & & .065 & .247 \\
\hline credit, insurance, real estate & & & & & .034 & .182 \\
\hline $\begin{array}{l}\text { data processing, R\&D, } \\
\text { business services }\end{array}$ & & & & & .049 & .215 \\
\hline other sectors & & & & & .033 & .179 \\
\hline union membership & & & & & .246 & .431 \\
\hline number of observations & \multicolumn{2}{|c|}{1915} & \multicolumn{2}{|c|}{1677} & \multicolumn{2}{|c|}{1607} \\
\hline
\end{tabular}

Notes: ${ }^{i}$ ) Men who were between 17 and 45 years old in 1997.

Source: Author's calculations based on GSOEP 1997 and 1998. 
Table 14: Descriptive statistics IV (Probit estimation of the employment status change of older workers ${ }^{i}$ between 1997 and 2001)

\begin{tabular}{lcccccc}
\hline \multirow{2}{*}{ specification } & \multicolumn{2}{c}{$(\mathbf{2})$} & \multicolumn{2}{c}{$(\mathbf{3})$} & \multicolumn{2}{c}{ (4) } \\
& Mean & St.Dev. & Mean & St.Dev. & Mean & St.Dev. \\
\hline employment status change & .272 & .445 & .268 & .443 & .271 & .445 \\
computer use & .466 & .499 & .449 & .498 & .455 & .498 \\
\hline number of observations & \multicolumn{3}{c}{886} & & 749 & \multicolumn{2}{c}{705} \\
\hline
\end{tabular}

Notes: ${ }^{i}$ ) Men who were between 46 and 60 years old in 1997.

Mean value and standard deviation of the other variables are largely the same as depicted in Table 11.

Source: Author's calculations based on GSOEP 1997 and 2001. 


\section{References}

Ahituv, A., and Zeira, J. (2000). Technical Progress and Early Retirement (discussion paper 2614). CEPR.

Aubert, P., Caroli, E., and Roger, M. (2004). New technologies, workplace organisation and the age structure of the workforce. mimeo.

Autor, D., Levy, F., and Murnane, R. (2002). Upstairs, Downstairs: Computers and Skills on Two Floors of a Large Bank. Industrial and Labor Relations Review, 55(3), 432-447.

Autor, D., Levy, F., and Murnane, R. (2003). The Skill Content of Recent Technological Change: An Empirical Exploration. Quarterly Journal of Economics, 116(4), 1279-1334.

Bartel, A., and Sicherman, N. (1993). Technological Change and Retirement Decisions of Older Workers. Journal of Labor Economics, 11(1), 162-183.

Berkel, B., and Börsch-Supan, A. (2003). Pension Reform in Germany - The Impact on Retirement Decisions (discussion paper 36/03). MEA.

Boockmann, B., and Zwick, T. (2004). Betriebliche Determinanten der Beschäftigung älterer Arbeitnehmer. Zeitschrift für Arbeitsmarktforschung, $37(1), 53-63$.

Borghans, L., and ter Weel, B. (2002). Do Older Workers Have More Trouble Using a Computer Than Younger Workers? Research in Labor Economics, 21, 139-173.

Borghans, L., and ter Weel, B. (2004). What Happens When Agent T Gets a Computer? The Labor Market Impact of Cost Efficient Computer Adoption. Journal of Economic Behavior And Organization, 54 (2), 137-151.

Chennells, L., and Van Reenen, J. (2002). Technical Change and the Structure of Employment and Wages: A Survey of the Microeconomic Evidence. In N. Greenan, Y. L'Horty, and J. Mairesse (Eds.), Productivity, Inequality and the Digital Economy (pp. 175-223). Cambridge, MA. 
De Grip, A., and Van Loo, J. (2002). The Economics of Skills Obsolescence: A Review. In A. De Grip, J. Van Loo, and K. Mayhew (Eds.), The Economics of Skills Obsolescence: Theoretical Innovations and Empirical Applications (Vol. 21, pp. 1-26). Amsterdam/Boston: JAI Press.

DiNardo, J., and Pischke, J.-S. (1997). The Returns to Computer Use Revisited: Have Pencils Changed the Wage Structure Too? Quarterly Journal of Economics, 112(1), 291-303.

Entorf, H., Gollac, M., and Kramarz, F. (1999). New Technologies, Wages, and Worker Selection. Journal of Labor Economics, 17(3), 464-491.

Entorf, H., and Kramarz, F. (1997). Does Unmeasured Ability Explain the Higher Wages of New Technology Workers? European Economic Review(41), 14891509.

Ernst, J. (1996). Alterserwerbstätigkeit und Ruhestand in Ostdeutschland. Arbeit, 5(2), 201-222.

Federal Statistical Office Germany. (1991). Statistical Yearbook Germany.

Friedberg, L. (2003). The Impact of Technological Change on Older Workers: Evidence From Data on Computer Use. Industrial and Labor Relations Review, 56(3), 511-529.

Greene, W. (2000). Econometric Analysis (4 ed.). New York University, USA.

Haisken-DeNew, J. P., and Frick, J. R. (2003). Desktop companion to the german socio-economic panel study (dtc). http://www.diw.de/english/sop/service/dtc/index.html.

Herfurth, M., and Kohli, M. (2003). Arbeit in einer alternden Gesellschaft - Problembereiche und Entwicklungstendenzen der Erwerbsbeteiligung Älterer. Opladen: Leske + Budrich.

Koller, B. (2001). Das Rentenalter wurde angehoben - zieht der Arbeitsmarkt mit? (Werkstattbericht 7). IAB.

Koller, B., and Gruber, H. (2001). Ältere Arbeitnehmer im Betrieb und als Stellenbewerber aus der Sicht der Personalverantwortlichen. MittAB, 34 (4), 479-505. 
Lazear, E. (1979). Why Is There Mandatory Retirement? Journal of Political Ecoomy, 87(6), 1261-1284.

Rosen, S. (1975). Measuring the Obsolescence of Knowledge. In F. T. Juster (Ed.), Education, Income, and Human Behavior, a report prepared for the Carnegie Commission on Higher Education, a Conference of the National Bureau of Economic Research (pp. 199-232). New York: McGraw-Hill.

Schleife, K. (2004). Dokumentation der Ruhestandsregelungen in verschiedenen Ländern (Dokumentation 04-01). ZEW.

Skirbekk, V. (2003). Age and Individual Productivity: A Literature Survey (working paper 2003-028). Max Planck Institute for Demographic Research.

Spitz, A. (2003). IT Capital, Job Content and Educational Attainment (discussion paper 03-04). ZEW.

Strotmann, H., and Hess, W. (2003). Eigenschaften und Beschäftigungschancen älterer Arbeitnehmer sowie betriebliche Maßnahmen für ältere Arbeitnehmer in Baden-Württemberg (short report 7). IAW.

Verbeek, M. (2000). A Guide to Modern Econometrics. John Wiley \& Sons, Ltd.

ZEW. (2003). IKT-Report: Unternehmen in der Internet-Ökonomie. ftp://ftp.zew.de/pub/zew-docs/div/IKTRep/IKT_Report_2003.pdf. 